\title{
Establishment of Natural Levels of Thiocyanate in Milk of Different Breeds of Cow and Murrah Breed of Buffalo
}

\author{
Kanthale PA ${ }^{1 *}$, Lal $\mathbf{D}^{1}$ and Datir RP² \\ ${ }^{1}$ Dairy Chemistry Division, ICAR-National Dairy Research Institute, Karnal, Haryana, India \\ ${ }^{2}$ Dairy Engineering Division, ICAR-National Dairy Research Institute, SRS, Bangalore, India
}

\begin{abstract}
Thiocyanate is a compound of Lactoperoxidase (LP) system in milk which helps naturally to preserve the milk. The malpractices of preserving the milk is done by adding thiocyanate in milk where chilling facilities does not exist. The natural thiocyanate level was determined to identify the externally added thiocyanate in milk of different breeds of cow and buffalo milk. Also, there is no study on the natural levels of thiocyanate in milk of cross breed (Karan Fries and Karan Swiss) and pure breed of cows (Sahiwal and Tharparkar) and Murrah breed of buffalo. The study was conducted on pooled milk samples of different breeds of cow and Murrah breed of Buffalo. The present investigation revealed the thiocyanate content of milk samples of individual crossbred Karan Fries and Karan Swiss cow and pure breeds Sahiwal and Tharparkar cow. The thiocyanate contents in individual milk samples of crossbred cows combined ranged from $6.01-8.92 \mathrm{mg} /$ litre with an average of $7.30 \pm 0.13$. Similarly, the thiocyanate contents in individual milk samples of pure breeds of cows combined ranged from $6.41-9.68 \mathrm{mg} /$ litre with an average of $7.87 \pm 0.17$. Likewise, the thiocyanate content in milk of all breeds of cows when combined and was determined and found in the ranged from 6.01-9.68 $\mathrm{mg} /$ litre with an average of $7.58 \pm 0.27$. In case of milk of Murrah buffaloes, the thiocyanate content in individual milk samples varied from 7.56 to $9.77 \mathrm{mg} / \mathrm{litre}$ with an average of $8.73 \pm 0.19 \mathrm{mg} / \mathrm{litre}$.
\end{abstract}

Keywords: Thiocyanate; Milk; Cow breeds; Murrah buffalo; LP system

\section{Introduction}

Milk and milk products have made very significant contributions to human nutrition. Milk being a perishable foodstuff, during transportation and storage, it undergoes microbial metabolism leading to breakdown of milk constituents which results into rise in acidity making the milk unacceptable and unfit for processing. However, to prevent the rejection of poor quality milk, the producers or the middlemen attempt to add thiocyanates irrationally as a component of LP system for preserving raw milk at ambient temperature. Such a practice of addition of thiocyanates to milk is not only against food laws, but it can also cause hazardous effect on the health of consumers, as thiocyanates are potent anti-thyroid substances and cause hypothyroidism at higher levels.

In bovine milk, the thiocyanate concentration reflects blood serum levels and varies with breed, species, udder health and type of feed [1]. Levels of thiocyanate between 1 to $10 \mathrm{ppm}$ have been reported for cow and buffalo milks [2-4]. However, there are no reports on the natural thiocyanate contents in milk of cows and buffaloes in India. Also, to identify added thiocyanate from natural thiocyanates, levels of naturally occurring thiocyanates in milk needs to be established.

\section{Materials and Methods}

\section{Collection of milk samples}

Fresh pooled raw milk samples used for the present study were collected separately from cows and buffaloes from the cattle yard of the National Dairy Research Institute, Karnal, Haryana, India where animals are kept under identical conditions of feeding and management.

\section{Establishment of natural levels of thiocyanates in cow and buffalo milk}

A total number of 75 individual milk samples comprising of 15 each from crossbred of Karan Fries, Karan Swiss cows, pure breeds of Sahiwal and Tharparkar cows, as well as Murrah breed of buffaloes, maintained under standard feeding and management practices at NDRI Karnal, were collected and analysed for their natural thiocyanate contents. In addition, a total number of 30 pooled milk samples comprising of 15 each from all breeds of cows pooled together and 15 from pooled milk samples of Murrah breed were also analysed for their natural thiocyanate contents. The thiocyanates levels were determined according to the method described in IDF [5] with slight modification in the procedure. The principle of method involves deproteinization of milk with 20 percent trichloroacetic acid (TCA), and on addition of ferric nitrate to the clear filtrate obtained; a ferric complex (orange to orange-red) is formed whose absorbance is measured at $460 \mathrm{~nm}$. The minimum level of detection by this method is 1 to $2 \mathrm{ppm}$ of thiocyanate

\section{Results and Discussion}

The accuracy and precision of the method was evaluated through recovery studies. For this, thiocyanate was added separately to pooled milk samples of cows and buffaloes at known concentrations of 0,15 , 30,45 , and $60 \mathrm{mg} /$ litre (equivalent to concentrations of potassium thiocyanate as $0,25,50,75$, and $100 \mathrm{mg} /$ litre of milk, respectively) and analyzed for thiocyanate content. The results obtained on 10 recovery trials carried out on cow and buffalo milks each at four concentrations comprising 80 samples are shown (Table 1). Pooled cow milk samples containing added thiocyanate at $15,30,45$, and $60 \mathrm{mg} /$ litre showed $\%$ recovery of $101.09 \pm 0.80,99.64 \pm 0.88,99.98 \pm 0.70$ and $101.28 \pm$ 0.66 at the respective concentrations. Similarly, in pooled buffalo milk

*Corresponding author: Kanthale PA, Dairy Chemistry Division, ICAR-National Dairy Research Institute, Karnal, Haryana, India, Tel: 0184-225-9023; E-mail: prashantdtc@gmail.com

Received September 18, 2017; Accepted October 09, 2017; Published October 16,2017

Citation: Kanthale PA, Lal D, Datir RP (2017) Establishment of Natural Levels of Thiocyanate in Milk of Different Breeds of Cow and Murrah Breed of Buffalo. J Food Process Technol 8: 698. doi: 10.4172/2157-7110.1000698

Copyright: (c) 2017 Kanthale PA, et al. This is an open-access article distributed under the terms of the Creative Commons Attribution License, which permits unrestricted use, distribution, and reproduction in any medium, provided the original author and source are credited. 


\begin{tabular}{|c|c|c|c|}
\hline \multirow{2}{*}{ Type of milk } & \multirow{2}{*}{$\begin{array}{l}\text { Levels of thiocyanate } \\
\text { (mg/litre) }\end{array}$} & \multicolumn{2}{|c|}{$\%$ Recovery } \\
\hline & & Range & Mean \pm S.E. \\
\hline \multirow{5}{*}{ Cow milk } & 0 (control) & - & - \\
\hline & 15 & $96.98-104.8$ & $101.09 \pm 0.80$ \\
\hline & 30 & $96.52-103.32$ & $99.64 \pm 0.88$ \\
\hline & 45 & $97.65-103.60$ & $99.98 \pm 0.70$ \\
\hline & 60 & $98.53-104.42$ & $101.28 \pm 0.66$ \\
\hline \multicolumn{2}{|c|}{ Average } & $96.52-104.8$ & $100.49 \pm 0.40$ \\
\hline \multirow{5}{*}{ Buffalo milk } & 0 (control) & - & - \\
\hline & 15 & $96.21-104.74$ & $100.22 \pm 0.91$ \\
\hline & 30 & $96.00-101.94$ & $98.11 \pm 0.67$ \\
\hline & 45 & $98.31-102.37$ & $100.32 \pm 0.44$ \\
\hline & 60 & $96.12-101.22$ & $99.16 \pm 0.52$ \\
\hline \multicolumn{2}{|c|}{ Average } & $96.00-104.74$ & $99.45 \pm 0.51$ \\
\hline Sow + Buffalo mil & Overall average & $96.00-104.80$ & $99.97 \pm 0.36$ \\
\hline
\end{tabular}

Table 1: Recovery studies on thiocyanate estimation in milk.

samples containing added thiocyanate at $15,30,45$, and $60 \mathrm{mg} /$ litre showed \% recovery of $100.22 \pm 0.91,98.11 \pm 0.67,100.32 \pm 0.44,100.32$ \pm 0.44 and $99.16 \pm 0.52$ at the respective concentrations. The average $\%$ recovery for cow and buffalo milks at the 4 levels of added thiocyanate studied was found to be $100.49 \pm 0.40$ and $99.45 \pm 0.51$ respectively, which ranged between 96.52-104.8 and 96.00-104.74, respectively. The overall average of recovery percentage for the pooled data of cow and buffalo milks was found to be $99.97 \pm 0.36$ which ranged between $96.00-104.8 \%$. Thus, it is evident from the data that the method showed good recovery for the added thiocyanate at $15,30,45$, and $60 \mathrm{mg} / \mathrm{litre}$, indicating that the method is accurate and precise for the purpose.

\section{Thiocyanate levels in milk of cows and buffaloes}

Thiocyanate contents in milk of different breeds of cows and Murrah buffaloes was studied in the present investigation and these are described below.

Establishment of natural levels of thiocyanate in milk of individual animals (cows of different breeds and Murrah buffaloes)

Table 2 shows the thiocyanate content of milk of individual animals of different breeds of cows and Murrah buffaloes collected from Institute herd. The thiocyanate content of milk samples of individual crossbred Karan Fries and Karan Swiss cows ranged from 6.01 to 8.92 $\mathrm{mg} /$ litre and 6.18 to $8.72 \mathrm{mg} /$ litre with an average of $7.07 \pm 0.18 \mathrm{mg} /$ litre and $7.54 \pm 0.18 \mathrm{mg} /$ litre, respectively. Similarly, the thiocyanate content of pure breeds Sahiwal and Tharparkar cows varied from 6.41 to $8.98 \mathrm{mg} /$ litre and 7.31 and $9.68 \mathrm{mg} /$ litre with an average of $7.38 \pm$ $0.22 \mathrm{mg} /$ litre and $8.36 \pm 0.20 \mathrm{mg} /$ litre, respectively. The thiocyanate contents in individual milk samples of crossbred cows combined ranged from $6.01-8.92 \mathrm{mg} /$ litre with an average of $7.30 \pm 0.13$. Similarly, the thiocyanate contents in individual milk samples of pure breeds of cows combined ranged from 6.41-9.68 mg/litre with an average of $7.87 \pm$ 0.17 . Likewise, when all breeds of cows were combined, the thiocyanate content in milk ranged from $6.01-9.68 \mathrm{mg} /$ litre with an average of 7.58 \pm 0.27 . The study revealed that there is no significant difference in the thiocyanate content of crossbreed cows (Karan Fries and Karan Swiss) and that of pure breeds of cows (Sahiwal and Tharparkar). However, the average thiocyanate content in milk of cows of Tharparkar breed was slightly higher than the milk of other breeds of cows (Karan Fries, Karan Swiss and Sahiwal) studied.

In case of milk of Murrah buffaloes, the thiocyanate content in individual milk samples varied from 7.56 to $9.77 \mathrm{mg} /$ litre with an average of $8.73 \pm 0.19 \mathrm{mg} /$ litre. However, when the data on all breeds of cows and buffaloes was combined, the thiocyanate content in milk was found to range from $6.41-9.77 \mathrm{mg} /$ litre with an average of $7.81 \pm$ $0.31 \mathrm{mg} / \mathrm{litre}$. The study revealed that the average thiocyanate content in milk of individual Murrah buffaloes was slightly higher than the average thiocyanate content observed in case of individual cows of different breeds studied.

\section{Establishment of natural levels of thiocyanates in pooled milk samples of cows of different breeds and Murrah buffaloes}

Table 3 shows thiocyanate content of pooled cow and buffalo milk samples collected from Institute herd. The thiocyanate content of pooled milk samples of cows of different breeds (Karan Fries, Karan Swiss, Sahiwal and Tharparkar) varied from 7.18 to $9.24 \mathrm{mg} /$ litre with an average of $8.24 \pm 0.15 \mathrm{mg} /$ litre. In case of buffalo milk, the thiocyanate content in pooled samples varied from 7.74 to $9.33 \mathrm{mg} / \mathrm{litre}$ with an average of $8.58 \pm 0.13 \mathrm{mg} /$ litre. When the data on pooled milk samples of cows and buffaloes was combined, the thiocyanate content in milk was found to be in the range from 7.18 to $9.33 \mathrm{mg} /$ litre with an average of $8.41 \pm 0.10 \mathrm{mg} /$ litre (Table 4). The study revealed that there was not much difference in the average thiocyanate content of pooled buffalo milk and pooled cow milk samples, although the content was slightly more in case of buffalo milk as compared to cow milk.

\begin{tabular}{|c|c|c|c|c|c|}
\hline \multirow{2}{*}{ Species } & \multirow{2}{*}{ Sr. No. } & \multirow{2}{*}{ Breed } & \multirow{2}{*}{$\begin{array}{c}\text { No. of } \\
\text { Samples }\end{array}$} & \multicolumn{2}{|c|}{$\begin{array}{c}\text { Thiocyanate content in milk } \\
\text { (mg/litre) }\end{array}$} \\
\hline & & & & Range & Mean \pm S.E. \\
\hline \multirow{7}{*}{ Cow } & 1 & Karan Fries & 15 & $6.01-8.92$ & $7.07 \pm 0.18$ \\
\hline & 2 & Karan Swiss & 15 & $6.18-8.72$ & $7.54 \pm 0.18$ \\
\hline & \multicolumn{2}{|c|}{ Crossbred cows combined } & 30 & $6.01-8.92$ & $7.30 \pm 0.13$ \\
\hline & 3 & Sahiwal & 15 & $6.41-8.98$ & $7.38 \pm 0.22$ \\
\hline & 4 & Tharparkar & 15 & $7.31-9.68$ & $8.36 \pm 0.20$ \\
\hline & \multicolumn{2}{|c|}{$\begin{array}{l}\text { Pure breeds of cows } \\
\text { combined }\end{array}$} & 30 & $6.41-9.68$ & $7.87 \pm 0.17$ \\
\hline & \multicolumn{2}{|c|}{$\begin{array}{l}\text { All breeds of cows } \\
\text { combined }\end{array}$} & 60 & $6.01-9.68$ & $7.58 \pm 0.27$ \\
\hline Buffalo & \multicolumn{2}{|r|}{ Murrah } & 15 & $7.56-9.77$ & $8.73 \pm 0.19$ \\
\hline \multicolumn{3}{|c|}{$\begin{array}{l}\text { All breeds of cows and buffaloes } \\
\text { combined }\end{array}$} & 75 & $6.41-9.77$ & $7.81 \pm 0.31$ \\
\hline
\end{tabular}

Table 2: Thiocyanate content in milk of individual animals of different breeds of cows and Murrah buffaloes.

\begin{tabular}{|c|c|c|c|}
\hline \multirow{2}{*}{ Species } & No. of milk & \multicolumn{2}{|c|}{$\begin{array}{c}\text { Thiocyanate content in milk } \\
\text { samples }\end{array}$} \\
\cline { 3 - 4 } & 15 & Range & Mean \pm S.E. \\
\hline Cow & 15 & $7.18-9.24$ & $8.24 \pm 0.15$ \\
\hline Buffalo & 30 & $7.18-9.33$ & $8.58 \pm 0.13$ \\
\hline Cows and buffaloes combined & $30.31 \pm 0.10$ \\
\hline
\end{tabular}

Table 3: Thiocyanate content in pooled milk of different breeds cows and Murrah buffaloes.

\begin{tabular}{|c|c|c|c|}
\hline \multirow[t]{2}{*}{ Species } & \multirow{2}{*}{$\begin{array}{l}\text { No. of milk } \\
\text { Samples }\end{array}$} & \multicolumn{2}{|c|}{$\begin{array}{l}\text { Thiocyanate content in milk } \\
\text { (mg/litre) }\end{array}$} \\
\hline & & Range & Mean \pm S.E. \\
\hline $\begin{array}{l}\text { All cows (cross breed and pure } \\
\text { breed) individual and pooled } \\
\text { combined together }\end{array}$ & 75 & $6.01-9.68$ & $7.91 \pm 0.33$ \\
\hline $\begin{array}{l}\text { Murrah buffaloes (individual and } \\
\text { pooled) combined }\end{array}$ & 30 & $7.56-9.77$ & $8.66 \pm 0.075$ \\
\hline $\begin{array}{l}\text { All cows and buffaloes } \\
\text { combined }\end{array}$ & 105 & $6.01-9.77$ & $8.29 \pm 0.38$ \\
\hline
\end{tabular}

Table 4: Thiocyanate content in milk of cows and buffaloes (Individual and pooled combined together). 
The above study revealed that the average thiocyanate content in milk of all cows (crossbreed and pure breed, individual and pooled, combined) and Murrah buffaloes (individual and pooled, combined) was observed to be $7.91 \pm 0.33 \mathrm{mg} /$ litre and $8.66 \pm 0.075 \mathrm{mg} / \mathrm{litre}$, with a range of 6.01-9.68 mg/litre and 7.56-9.77 mg/litre, respectively (Table 4). When the data on all the milk samples of cows and buffaloes was combined, the average thiocyanate content in milk was found to be $8.29 \pm 0.38 \mathrm{mg} / \mathrm{litre}$ with a range of $6.01-9.77 \mathrm{mg} / \mathrm{litre}$.

In literature, the thiocyanate concentration of bovine milk has been reported to vary with breed, species and type of feed, and has been estimated to range between 1 to $15 \mathrm{ppm}$ i.e., $1-15 \mathrm{mg} /$ litre [6]. Cows maintained on natural pastures (outdoor feeding) yield milk containing higher concentrations of thiocyanate than on lay pastures (indoor feeding) which have limited range of grasses $[7,8]$

Thiocyanate level of 1-10 ppm was reported by Lawrence [8] and Michajlovskiji et al. [9] in bovine milk. Bjorck et al. [2] during their experiments in Kenya reported that the pooled milk samples collected from three different collecting centres, contained 3.2 to $4.6 \mathrm{ppm}$ of SCN. Harnulv and Kandasamy [3] in their studies in Sri-Lanka observed SCN- level of $5.4 \mathrm{ppm}$ in buffalo milk.

\section{Conclusion}

A detailed study based on 80 observations ( 10 samples each at four concentrations of added thiocyanate at $0,15,30,45$ and $60 \mathrm{mg} / \mathrm{litre}$ of cow and buffalo milks separately) revealed that the overall average recovery percentage was found to be $99.97 \pm 0.36 \mathrm{mg} /$ litre which ranged between $96.00-104.8 \%$. This indicated that the method followed in the study was very accurate and precise for the purpose. The natural thiocyanate content in individual and pooled milks of crossbred cows (Karan swiss and Karan fries), pure breeds of cows (Sahiwal and Tharparkar) and Murrah Buffaloes was studied.

The thiocyanate contents in individual milk samples of crossbred cows combined together ranged from 6.01-8.92 $\mathrm{mg} /$ litre with an average of $7.30 \pm 0.13$. Similarly, the thiocyanate contents in individual milk samples of pure breed cows combined ranged from $6.41-9.68 \mathrm{mg} /$ litre with an average of $7.87 \pm 0.17$. In case of milk of Murrah buffaloes, the thiocyanate content in individual milk samples varied from 7.56 to $9.77 \mathrm{mg} /$ litre with an average of $8.73 \pm 0.19 \mathrm{mg} /$ litre.

The thiocyanate contents of pooled milk samples of cows of different breeds (Karan Fries, Karan Swiss, Sahiwal and Tharparkar) varied from 7.18 to $9.24 \mathrm{mg} /$ litre with an average of $8.24 \pm 0.15 \mathrm{mg} /$ litre. In case of buffalo milk, the thiocyanate content in pooled samples varied from 7.74 to $9.33 \mathrm{mg} /$ litre with an average of $8.58 \pm 0.13 \mathrm{mg} /$ litre.

The study further revealed that the average thiocyanate content naturally present in milk of all cows (crossbred and pure breed, individual and pooled, combined) based on 75 records and Murrah buffaloes (individual and pooled, combined) based on 30 records was observed to be $7.91 \pm 0.33 \mathrm{mg} /$ litre and $8.66 \pm 0.075 \mathrm{mg} / \mathrm{litre}$, with a range of 6.01-9.68 $\mathrm{mg} / \mathrm{litre}$ and 7.56-9.77 $\mathrm{mg} /$ litre, respectively. When the data on all the milk samples of cows and buffaloes was combined, the average thiocyanate content in milk based on 105 records was found to be $8.29 \pm 0.38 \mathrm{mg} /$ litre with a range of 6.01-9.77 mg/litre. In general, the natural thiocyanate content was slightly more in case of buffalo milk as compared to cow milk.

\section{Acknowledgements}

The authors are thankful to the Department of Dairy Chemistry, National Dairy Research Institute, Karnal, Haryana for providing necessary fund and facilities to conduct the study.

\section{References}

1. Kussendrager KD, Van Hooijdonk ACM (2000) Lactoperoxidase: Physico chemical properties, occurrence, mechanism of action and applications. British J Nutri 84: 19-25.

2. Bjorck L, Claesson O, Schuthes W (1979) The lactoperoxidase-thiocyanatehydrogen peroxide system as a temporary preservative for raw milk in developing countries. Milchwissenchaft 34: 726-729.

3. Harnulv BG, Kandasamy C (1982) Increasing the keeping quality of milk by activation of its lactoperoxidase system: Results from Sri-Lanka. Milchwissenchaft 37: 454-457.

4. Davidson PM (1997) Chemical preservation and natural antimicrobia compounds. Food microbiology: Fundamentals and frontiers, ASM Press, Washington D.C., USA. pp: 520-556.

5. IDF (1988) Code of practices for the preservation of milk by the lactoperoxidase system. Bull Int Dairy Fed 234: 1-15.

6. Klebanoff SJ, Clem WH, Luebke RG (1966) The peroxidase-thiocyanatehydrogen peroxide antimicrobial system. Biochemicaet Biophysica Acta 117 63-72.

7. Boulange M, Vert $P(1963)$ Seasonal fluctuation in thiocyanate in cow's milk. Physiol (Paris) 55: 204-205.

8. Lawrence AJ (1970) The thiocyanate content of milk. Division of Dairy Res CSIRO, Melbourne, Australia.

9. Michajlovskiji N, Thurkow B, Weuffen, W (1982) Omega-3 fatty acids: Occurrence in plant foods. VEB Verlag Volk and Gesundheil, Berlin. pp: 110-112. 